\title{
MENERAPKAN METODE COOPERATIVE LEARNING DALAM PEMBELAJARAN PENDIDIKAN AGAMA ISLAM
}

\author{
Oleh: Syukri Fathudin Achmad Widodo \\ (Fakultas Teknik - UNY)
}

\begin{abstract}
Abstrak
Cooperative learning adalah metode pembelajaran dengan prinsip belajar untuk sukses bersama. Cooperative Learning biasa disebut dengan tutorial teman sebaya, artinya metode pembelajaran yang dilakukan dengan melibatkan siswa untuk saling membantu siswa yang lainnya. Cooperative learning sebagai salah satu alternatif metode pembelajaran dapat dijadikan pilihan bagi para pendidik mulai jenjang pendidikan dasar sampai pendidikan tinggi.

Dengan cooperative learning diharapkan mahasiswa dapat meningkatkan hasil belajarnya dan interaksi sosial dengan sesamanya dapat terjalin dengan baik. Implementasi cooperative learning pada kelas akan merubah paradigma cara belajar dengan suasana tradisional yang berfokus pada kegiatan belajar mengajar yang berpusat pada dosen menjadi kegiatan belajar mengajar yang berpusat pada mahasiswa. Dengan demikian, diharapkan penguasaan pengetahuan dan keterampilan mahasiswa menjadi lebih baik selain juga mengembangkan tanggung jawab, pemahanan pengetahuan, empati, dan interaksi sosial dengan sesama siswa lainnya, sehingga pendidikan berbasis mutu tidak hanya sebagai konsep tetapi juga perbaikan berkelanjutan dalam pendidikan menuju ke arah lebih baik.

Tujuan Pendidikan Agama Islam lebih merupakan suatu upaya untuk membangkitkan intuisi agama dan kesiapan rohani dalam mencapai pengalaman transendental. Dengan demikian tujuan utamanya bukanlah sekedar mengalihkan pengetahuan dan keterampilan (sebagai isi pendidikan), melainkan lebih merupakan suatu ikhtiar untuk menggugah fitrah insaniyah (to stir up certain innate powers), sehingga mahasiswa bisa menjadi penganut atau pemeluk agama yang taat dan baik (Muslim paripurna). Sedangkan pendidikan pada umumnya, bertujuan lebih menitikberatkan pada pemberian pengetahuan dan ketrampilan khusus dan secara ketat berhubungan dengan pertumbuhan serta pemilahan areal kerja yang diperlukan dalam masyarakat. Dalam hal ini hubungan interaksi lebih bersifat kognitif-psikomotorik, dan kurang banyak menyentuh kealaman rohani serta sifat-sifat watak kepribadian manusia.
\end{abstract}

Menerapkan Metode Cooperative Learning dalam Pembelajaran Pendidikan 15 Agama Islam (Syukri Fathudin Achmad Widodo) 


\section{Pendahuluan}

Manusia adalah makhluk yang berakal budi. Kekhasan inilah yang menjadi pembeda manusia dengan makhluk lainnya. Manusia dapat berpikir, menentukan pilihannya, dan menentukan tindakan berdasarkan akal dan pikirannya. Selain itu manusia diciptakan Allah sebagai makhluk yang paling mulia di antara makhluk-makhluk lainnya.

Dalam kehidupannya, manusia butuh peran orang lain, maka ia disebut juga sebagai makhluk sosial. Sebagai makhluk sosial ia hanya dapat berkembang apabila berinteraksi dan hidup berdampingan dengan manusia lainnya. Oleh karenanya, untuk dapat berkembang secara utuh, ia harus berinteraksi dan membutuhkan orang lain.

Sebagai makhluk ciptaan Allah, manusia memerlukan pula relasi yang baik dengan Allah (hablumminnallah) dan makhluk sekitar tempat ia hidup (hablumminannas). Dengan berdoa, memuji, meluhurkan, memohon, dan berserah diri kepada Allah manusia akan menemukan ketenangan batin, keberkahan hidup, ketenteraman dan mampu memaknai hidupnya. Interaksi dengan alam secara selaras merupakan bagian dari tugas dan keharusan manusia dalam hidupnya di alam ini agar dicapai ketenangan, ketenteraman dan kejayaan. Dari berbagai karakteristik manusia ini dapatlah dirumuskan bahwasannya manusia merupakan sosok yang utuh dan sempurna yang didukung dengan unsur rasionalitas, kesadaran, akal budinya (pengetahuan), mengembangkan segi spiritualitas, moralitas, sosialitas, keselarasan dengan alam, serta rasa dan emosinya.

Dalam konteks pendidikan maka bila manusia yang kita inginkan adalah manusia yang utuh dalam semua segi kemanusiaan seperti di atas maka jelas bahwa tujuan pendidikan sebenarnya adalah untuk membentuk pribadi manusia secara utuh. Oleh karenanya, dalam pendidikan segi-segi kemanusiaan seperti spiritualitas, mentalitas, moralitas, sosialitas, rasa, dan rasionalitas perlu mendapat porsi yang memadai.

Pendidikan bukan hanya sekedar menekankan sisi kognitifnya saja tetapi harus juga menekanakan segi emosi, rohani, solidaritas, dan sebagainya. Pendidikan yang hanya menekankan dari segi pengetahuan, apalagi hanya nilai ujian saja akan mengakibatkan anak didik tidak berkembang secara utuh. Akibatnya timbul tindakantindakan yang jauh dari nilai-nilai moral seperti tawuran pelajar, narkotika, obat terlarang dan sebagainya (Suparno, 2002). 
Penerapan prinsip ini menjadi relevan di tengah kritik tajam terhadap dunia pendidikan saat ini mengenai rendahnya kemampuan peserta didik dalam aspek logika, estetika, etika, dan kinestetika. Cukup lama pendidikan terutama Pendidikan Agama Islam terlalu menekankan segi kognitif, sedangkan segi spiritual, emosional, sosial, fisik, seni kurang mendapatkan tekanan. Akibatnya anak didik kurang berkembang secara menyeluruh. Dalam pembelajaran yang ditekankan hanya to know (untuk tahu) sedangkan unsur pendidikan yang lain seperti to do (melakukan), to live together (hidup bersama), dan to be (menjadi) kurang menonjol. Pendidikan Agama sudah saatnya diletakkan pada empat pilar belajar yaitu: belajar mengetahui (learning to know), belajar melakukan (learning to do), belajar hidup dalam kebersamaan (learning to live together) dan belajar menjadi diri sendiri (learning to be). Selain itu perlu dikembangkan kemampuan adaptasi terhadap berbagai perubahan dan perkembangan kehidupan.

\section{Cooperative Learning}

Cooperative learning oleh Barbara Lubbe (1992: 45) didefinisikan sebagai a successful teaching strategy in which small teams, each with students of different level of ability, use a variety of learning activities to improve their understanding of a subject. Each member of a team is responsible not only for learning what is taught but also for helping teammates leam, thus creating an atmosphere (http:// www.cde.ca.gov/iasa/cooplrng2.html). Berdasarkan definisi tersebut, cooperative learning merupakan strategi pembelajaran untuk mencapai sukses bersama dalam suatu kelompok kecil, yang beranggotakan para siswa dengan tingkat kemampuan yang berbeda. Cooperative learning dimaksudkan untuk meningkatkan pemahaman terhadap materi pelajaran. Tiap anggota kelompok merespon bukan saja materi pelajaran yang diajarkan tetapi juga membantu belajar anggota tim lainnya agar berkreasi dalam suasana kondusif.

Manusia adalah makhluk sosial, karena itu kegiatan apa pun yang dilakukan oleh seseorang pasti berhubungan dengan orang lain. Melalui konsep ini model pembelajaran cooperative learning atau model pembelajaran gotong royong dilaksanakan. Kunci utamanya adalah kerja sama, karena melalui kerja sama hal yang sangat sulit pun dapat dipecahkan dengan mudah. Sebagai kebutuhan dasar, kerja sama adalah syarat keberlangsungan hidup. Individu, keluarga, organisasi ataupun sekolah ada karena kerja sama. Dalam pendidikan, kerja sama lebih kepada kegiatan belajar yang dilakukan secara berkelompok.

Menerapkan Metode Cooperative Learning dalam Pembelajaran Pendidikan 17 Agama Islam (Syukri Fathudin Achmad Widodo) 
Mahasiswa dibagi dalam kelompok-kelompok kecil untuk kemudian melaksanakan kegiatan bersama di mana segala penyelesaian atas permasalahan yang diambil diputuskan bersama-sama anggota kelompok lain. Pada pembelajaran yang menekankan keterampilan model belajar seperti ini dapat memacu mahasiswa yang berkemampuan kurang untuk meningkatkan keterampilannya minimal sama dengan teman anggota kelompoknya.

Untuk melaksanakan model pembelajaran cooperative learning ada beberapa hal yang harus diperhatikan antara lain model pengelompokan yang berarti mengumpulkan mahasiswa dalam lingkup yang lebih kecil di mana masing-masing pribadi berbeda namun harus tetap bekerja sama memperoleh yang terbaik, menata ulang ruang kelas agar lebih kondusif dan menciptakan suasana kelas yang membuat mahasiswa dapat fokus pada pembelajaran. Hal ini tidak mudah dilakukan karena mahasiswa harus memiliki toleransi yang tinggi dan kehilangan karakter pribadi, karena harus menyesuaikan diri dengan anggota kelompok. Terlepas dari hal tersebut, tujuan utama model pembelajaran cooperative learning adalah menanamkan pentingnya kerja sama, sikap empati, dan meningkatkan pengetahuan agar kelak menjadi generasi yang tidak hanya cakap tetapi juga memiliki tanggung jawab dan tingkat kepedulian sosial yang tinggi.

Selama ini dalam model pembelajaran konvensional mahasiswa bersaing satu sama lain untuk mendapatkan yang terbaik, teman dianggap sebagai lawan yang perlu dikalahkan dengan cara apa pun. Sikap ini bila dibiarkan berkembang akan mempengaruhi pribadi mahasiswa menjadi manusia yang tidak peduli dengan orang lain. Baik atau buruknya orang lain dianggap sebagai lawan yang harus dikalahkan, padahal tujuan pendidikan yang baik tidaklah demikian.

Pendidikan dan pengajaran tidak dapat dicampuradukkan, karena pendidikan cenderung merupakan proses yang bernafaskan pada agama, sedangkan proses pengajaran adalah proses mencerdaskan yang tidak bernafaskan apa-apa dan sangat tergantung para pelaku pengajarnya. Paradigma baru Pendidikan Agama Islam ini nampaknya menuntut para pengajarnya untuk mampu mengintegrasikan nilai-nilai Ilahiyah-duniawiyah dalam proses pendidikan dan pengajarannya dalam satu semester.

Pendidikan Agama Islam di Perguruan Tinggi Umum (PTU) berguna untuk membantu terbinanya mahasiswa yang beriman dan bertaqwa kepada Allah Swt., berbudi pekerti luhur, berpikir filosofis, bersikap rasional dan dinamis, berpandangan luas, ikut serta 
mewujudkan Indonesia yang utuh, aman, sejahtera yang diridoi Allah Swt. Tujuan pendidikan agama lebih merupakan suatu upaya untuk membangkitkan intuisi agama dan kesiapan rohani dalam mencapai pengalaman transendental. Dengan demikian tujuan utamanya bukanlah sekedar mengalihkan pengetahuan dan keterampilan (sebagai isi pendidikan), melainkan lebih merupakan suatu ikhtiar untuk menggugah fitrah insaniyah (to stir up certain innate powers), sehingga peserta didik bisa menjadi penganut atau pemeluk agama yang taat dan baik (Muslim paripurna). Sedangkan pendidikan pada umumnya, bertujuan lebih menitikberatkan pada pemberian pengetahuan dan ketrampilan khusus dan secara ketat berhubungan dengan pertumbuhan serta pemilahan areal kerja yang diperlukan dalam masyarakat. Dalam hal ini hubungan interaksi lebih bersifat kognitif-psikomotorik, dan kurang banyak menyentuh kealaman rohani serta sifat-sifat watak kepribadian manusia.

Lebih jauh Pendidikan Agama Islam bukan merupakan kegiatan yang terpisah dari aspek-aspek kehidupan masyarakat luas yang berlangsung dalam konteks keselarasan maupun keseimbangan dengan kegiatan-kegiatan, baik perorangan maupun kelembagaannya dan dalam posisi yang saling memperkokoh atau memperkuat antara yang satu dengan yang lain. Kampus hanya merupakan salah satu kontributor dan bukan yang utama. Di luar kampus banyak pihak yang tidak kalah penting peranannya yang ikut memberikan kontribusi pelaksanaan pendidikan agama (seperti rumah/keluarga, kawan bermain dan suasana kehidupan beragama di masyarakat/ lingkungannya). Dengan demikian keterlibatan pranata sosial kemasyarakatan yang lain ikut memberikan andil bagi keberhasilannya baik dari sisi kuantitas maupun kualitas pendidikan itu sendiri.

Selain itu dalam pelaksanaan Pendidikan Agama Islam di Perguruan Tinggi, juga diperlukan suasana interaksi antara dosen dan peserta didik yang sifatnya lebih mendalam, lahir dan batin. Figur dosen Pendidikan Agama Islam tidak sekedar sebagai penyampai materi kuliah tetapi lebih dari itu ia adalah sumber inspirasi "spiritual" dan sekaligus sebagai pembimbing, sehingga terjalin hubungan pribadi antara dosen dan peserta didik yang cukup dekat dan mampu melahirkan keterpaduan bimbingan rohani dan akhlak dengan materi pembelajarannya. Karena itu, fungsi dan peran dosen agama tidak cukup hanya bermodal "profesional" semata-mata tetapi perlu didukung oleh kekuatan "moral".

Menerapkan Metode Cooperative Learning dalam Pembelajaran Pendidikan 19 Agama Islam (Syukri Fathudin Achmad Widodo) 
Demikian pula tentang mutu Pendidikan Agama Islam dan pencapaian prestasi peserta didiknya tidak dapat begitu saja diukur lewat tabel-tabel statistik. Mutu dan keberhasilan Pendidikan Agama Islam harus dapat diukur dengan totalitas peserta didik sebagai pribadi.

\section{Teknik Pembelajaran Cooperative Learning}

Teknik pelaksanaan yang digunakan dalam pelaksanaan cooperative learning di ruang kelas adalah merubah kelas yang terpusat pada dosen menjadi kelas yang terpusat pada mahasiswa dan kegiatan belajar mahasiswa. Untuk itu diperlukan penataan ulang ruang kelas agar tercipta suasana kelas yang kondusif. Cara ini adalah cara termudah dan paling efektif untuk mengubah fokus kelas. Penataan kursi-kursi yang semula berderet rapi memanjang dan sejajar dibuat menjadi lingkaran-lingkaran kecil dan lingkaran besar. Penataan ini juga hendaknya melibatkan para siswa sehingga siswa merasa turut berpartisipasi menciptakan lingkungan belajar yang baru.

Adapun teknik pembelajaran cooperative learning dapat digunakan dalam berbagai bahan pelajaran, situasi ataupun mahasiswa. Namun untuk melaksanakannya diperlukan komitmen dan profesionalitas pendidik untuk selalu meningkatkan kemampuan yang didasari oleh pemikiran-pemikiran reflektif yang berhubungan dengan kegiatannya bersama siswa, bersama rekan guru, atasan serta pengetahuan tentang teori yang berhubungan dengan bidang pengajarannya.

Untuk mendukung profesionalitas, pendidik dituntut melalukan inovasi dan eksprorasi pembelajaran. Menurut Lie (2004: 54) terdapat teknik-teknik pembelajaran dalam cooperative learning sebagai berikut :

1. Mencari Pasangan

Adalah teknik memasangkan kartu satu dengan lainnya yang berisi pernyataan yang cocok. Misalkan kartu A berisi kelainan kulit akibat jamur, dan kartu yang cocok sebagai pasangannya adalah penyakit kulit panu, kadas dan kurap.

2. Bertukar Pasangan

Siswa memiliki pasangan lalu mengerjakan tugas yang diberikan bersama, kemudian berganti pasangan dan kembali mendiskusikan

tugas. Setelah saling menanyakan dan mengukuhkan jawaban 
siswa kembali ke pasangan semula dan memberikan informasi yang didapat dari pasangan yang lainnya.

3. Berpikir-Berpasangan-Berempat

Guru membagi siswa dalam kelompok berisi empat orang dengan satu permasalahan. Setiap siswa mengerjakan tugas tersebut sendiri kemudian didiskusikan dengan pasangan dalam kelompoknya. Keempatnya kemudian berkumpul dan masingmasing membagikan hasil kerjanya pada anggota lain dalam satu kelompok.

4. Berkirim Salam Dan Soal

Setiap kelompok menuliskan beberapa pertanyaan lalu dikirimkan oleh utusan ke kelompok lain. Tiap kelompok lalu menjawab pertanyaan yang ada, setelah selesai, jawaban kemudian dicocokan dengan jawaban kelompok yang membuat soal.

5. Kepala Bernomor

Teknik ini memberikan kesempatan kepada siswa untuk sasling membagikan ide dan mempertimbangkan jawaban yang paling tepat dan mendorong siswa meningkatkan semangat kerja sama.

6. Kepala Bernomor Terstruktur

Merupakan bentuk modifikasi dari kepala bernomor, disini siswa belajar melaksanakan tanggung jawab pribadinya yang berkaitan dengan rekan-rekan kelompoknya.

7. Dua Tinggal Dua Tamu

Memberi kesempatan kepada kelompok untuk membagikan hasil dan informasi dengan kelompok lain.

8. Keliling Kelompok

Masing-masing anggota kelompok mendapat kesempatan untuk memberikan kontribusi mereka dan mendengarkan pandangan dan pemikiran anggota yang lain.

9. Kancing Gemerincing

Masing-masing anggota kelompok mendapat kesempatan untuk mendengarkan pandangan dan pemikiran anggota lain secara bergantian.

Menerapkan Metode Cooperative Learning dalam Pembelajaran Pendidikan 21 Agama Islam (Syukri Fathudin Achmad Widodo) 
10. Keliling Kelas

Masing-masing kelompok mendapatkan kesempatan utnuk memamerkan hasil kerja mereka dan melihat hasil kerja kelompok lain.

\section{Lingkaran Kecil Lingkaran Besar}

Setiap siswa saling membagi dan bertukar informasi satu sama lain pada saat yang bersamaan.

\section{Tari Bambu}

Merupakan modifikasi lingkaran besar lingkaran kecil. Siswa belajar saling berhadapan dan saling berbagi informasi pada saat yang bersamaan.

\section{Jigsaw}

Dalam teknik ini guru memperlihatkan skema atau latar belakang pengalaman siswa dan membantu mengaktifkannya agar bahan pelajaran menjadi lebih bermakna.

\section{Bercerita Berpasangan \\ Merupakan bentuk modifikasi dari jigsaw.}

\section{Evaluasi Proses}

Menurut Roger dan David Johnson (1994, dalam Anita Lie, 2004: 88) terdapat beberapa prosedur dan unsur yang harus diterapkan dalam sistem pengajaran cooperative learning, antara lain: 1) tanggung jawab pribadi, dan 2) saling ketergantungan positif. Dalam hal ini mahasiswa mendapatkan nilai pribadi dan nilai kelompok. Saat belajar mahasiswa saling membantu memahami dan menemukan jalan keluar dari sebuah permasalahan namun saat tes setiap mahasiswa bertanggung jawab atas nilai masing-masing dan menerima nilai pribadi. Selain itu nilai pribadi juga diperoleh dengan memperlihatkan perilaku yang hendak dicapai. Nilai kelompok dapat dibentuk dengan beberapa cara. Pertama nilai kelompok bisa diambil dari nilai terendah yang didapat mahasiswa dalam kelompok, kedua nilai kelompok juga dapat diambil dari rata-rata nilai semua anggota kelompok.

Kelebihan dan kekurangan dari model evaluasi ini adalah: 1) Semangat gotong royong tertanam baik; 2) Peserta didik lebih bertanggung jawab atas tindakannya dan kegiatan belajar; 3) Dapat menerapkan pengetahuan dengan baik dan segera melakukan 
perbaikan bila diperlukan; 4) Memiliki rasa empati terhadap sesama dan lingkungannya serta lebih menghormati hak milik orang lain; 5) Peserta didik dengan kemampuan akademis tinggi merasa dirugikan dan dimanfaatkan oleh nilai rekannya yang lemah dan merasa tidak mendapatkan apa-apa; dan 6) Peserta didik yang lemah merasa bersalah karena sumbangan nilainya paling rendah.

\section{Visi dan Misi Pendidikan Agama Islam}

Visi PAI di Perguruan Tinggi Umum adalah menjadikan ajaran Islam sebagai sumber nilai, dan pedoman yang mengantarkan mahasiswa dalam mengembangkan profesi dan kepribadian Islami. Sedang misinya adalah terbinanya mahasiswa yang beriman, bertaqwa, berilmu, dan berakhlak mulia, serta menjadikan ajaran Islam sebagai landasan berpikir dan berperilaku dalam pengembangan profesi.

Begitu strategisnya mata kuliah PAI ini, sehingga proses pembelajarannya secara nonformal tidak hanya tanggung jawab dosen PAI semata yang hanya ditempuh pada semester awal serta berbobot hanya 2 sks, melainkan dosen lain yang seaqidah dapat pula mengintegrasikan dengan mata kuliah yang diampunya. Hal ini sungguh pekerjaan yang mulia dan bernilai ibadah tentunya.

Seiring dengan diberlakukan pendidikan berbasis kompetensi yang meletakkan peserta didik sebagai pusat belajar (student centered) maka dosen memposisikan sebagai fasilitator dan motivator. Dalam proses pembelajaran mestinya dikondisikan yang menyenangkan dan bermakna, karena yang disampaikan tidak saja pengetahuan melainkan pendidikan nilai-nilai kebenaran yang berasal dari Allah, Tuhan yang Maha Kuasa. Ini dapat dimengerti karena Pendidikan Agama bukan saja digarap pada aspek kognisi - psikomotorik saja melainkan afeksi lebih dominan karena merupakan fungsi dari keyakinan. Seseorang yang yakin bahwa dengan melakukan perbuatan itu akan membawa dampak positif bagi dirinya, maka ia akan bersikap untuk melakukan perbuatan tersebut. Sebaliknya jika perbuatan itu akan membawa dampak negatif bagi dirinya, maka ia akan menunjukkan sikap untuk menolaknya. Keyakinan untuk berbuat sesuatu yang mendasari seseorang ini biasa dinamakan behavior belief (Zamroni, 1992).

Menerapkan Metode Cooperative Learning dalam Pembelajaran Pendidikan 23 Agama Islam (Syukri Fathudin Achmad Widodo) 


\section{Menuju Pembelajaran Berbasis Ketaqwaan}

Dapat dimengerti bahwa tujuan akhir dari pembelajaran PAI adalah menciptakan manusia yang beriman dan bertaqwa kepada Allah SWT. serta cerdas lahir dan batin. Hal ini sejalan dengan Renstra UNY yang menjadikan manusia yang cendekia - mandiri bernurani.

Proses pembelajaran yang dilakukan meliputi studium general, kuliah di kelas, tutorial (model cooperative learning), dan pesantren sehari. Studium general atau kuliah umum adalah salah satu awal mengikuti proses perkuliahan PAI, yang dilaksanakan secara integrative antara dosen PAI dengan tim tutorial PAI UNY, bertempat di Auditorim UNY. Kuliah di kelas adalah interaksi dosen dan mahasiswa di ruang belajar di kelas masing-masing dengan strategi ceramah, tanya jawab, penugasan, dan diskusi kelompok. Tutorial (pendampingan) adalah proses pembelajaran yang dilakukan tim tutorial PAI untuk membantu mahasiswa dalam memberantas BacaTulis Alqur;an dan meningkatkan silaturrahim antarmahasiswa UNY yang diselenggarakan di luar jam kuliah di kela. Sedangkan tempatnya dapat di halaman rektorat UNY, masjid mujahidin, dan lain-lain. Pesantren sehari adalah sarana mengintegrasikan pemahaman PAI baik dari hasil kuliah umum (stadium general), kuliah di kelas, dan tutorial.

\section{Penutup}

Adalah tugas kita bersama untuk membangun manusia yang sehat lahir dan batin menuju insan kamil. Sementara dosen PAI dan Tim Tutorial PAI sebagai penanggungjawab pelaksanaan proses pembelajaran berfungsi sebagai konduktor dan motivator mahasiswa menuju cita-cita mata kuliah PAI pada khususnya dan cita-cita UNY pada umumnya. Wallahu A'lam.

\section{Daftar Pustaka}

A. Malik Fadjar. (1998). Visi Pembaruan Pendidikan Islam, Jakarta, LP3NI.

Anita Lie. (2004). Cooperative Learning. Jakarta: Grassindo.

(http: // www.cde.ca.gov/iasa/cooplrng2.html). 
Suparno. (2002). Reformasi Pendidikan Sebuah Rekomendasi. Yogyakarta: Kanisius.

Syukri F. Achmad Widodo. (2003). Silabus Pendidikan Agama Islam. FT, UNY.

(2004). Diktat Pendidikan Agama Islam. Yogyakarta: (2005). "Peningkatan Mutu Pendidikan Agama Islam Melalui Kurikulum Berbasis Kompetensi”, Jurnal HumanikaMKU UNY Volume II Maret - Agustus 2005.

(2005). "Manajemen Peningkatan Mutu Pendidikan Kejuruan”, Jurnal Dinamika Volume II, November 2005.

Wagiran (2003). "Meningkatkan kualitas pembelajaran melalui penerapan pembelajaran cooperative learning dalam matakuliah Teori Proses Pemesinan III pada mahasiswa jurusan Teknik Mesin FT. Universitas Negeri Yogyakarta”. Jurnal Dinamika Volume 1, Nomor 1, Mei 2003.

Zamroni. (1992). Pengantar Pengembangan Teori Sosial. Yogyakarta: Tiara Wacana.

\section{Biodata Penulis}

Syukri Fathudin Achmad Widodo, S.Ag, M.Pd., dilahirkan di Ambarawa, 12 Maret 1975, Pendidikan SI diselesaikannnya tahun 1998 di STAIN Salatiga jurusan Tarbiyah, sedangkan S2 pada PPS UNNES Semarang jurusan Manajemen Pendidikan. Sejak tahun 2002 sebagai staf pengajar MKU dan jurusan Teknik Mesin Fakultas Teknik UNY Yogyakarta, khususnya mata kuliah Pendidikan Agama Islam.

Menerapkan Metode Cooperative Learning dalam Pembelajaran Pendidikan 25 Agama Islam (Syukri Fathudin Achmad Widodo) 